ORP-53939 -FP

Revision 0

\title{
The effect of high-level waste glass composition on spinel liquidus temperature
}

Prepared for the U.S. Department of Energy

Assistant Secretary for Environmental Management

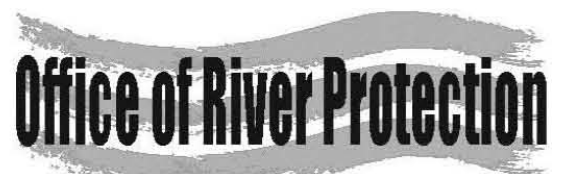

P.O. Box 450

Richland, Washington 99352 
ORP-53939 -FP

Revision 0

\section{The effect of high-level waste glass composition on spinel liquidus temperature}

\author{
A. A. Kruger \\ Department of Energy - Office of River Protection \\ B. J. Riley \\ Pacific Northwest National Laboratory \\ J. V. Crum \\ Pacific Northwest National Laboratory
}

\author{
P. Hrma \\ POSTECH \\ J. Matyas \\ Pacific Northwest National Laboratory \\ P. Hrma \\ Pacific Northwest National Laboratory
}

Date Published

November 2012

To be Presented at

10th International Symposium on Crystallization in Glasses and Liquids

Clausthal University of Technology

Goslar, Germany

$09 / 23 / 2012$

Published in

Journal of Non-Crystalline Solids

Prepared for the U.S. Department of Energy

Assistant Secretary for Environmental Management

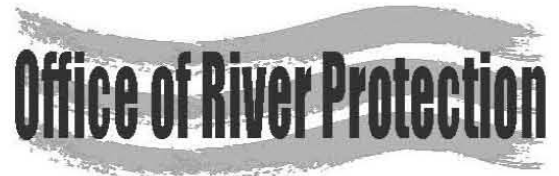

P.O. Box 450

Richland, Washington 99352

Copyright License

By acceptance of this article, the publisher and/or recipient acknowledges the U.S. Government's right to retain a non exclusive, royalty-free license in an to any copyright covering this paper.

\section{APPROVED}

By Janis D. Aardal at 9:16 am, Nov 15, 2012 
ORP-53939 -FP

Revision 0

\section{LEGAL DISCLAIMER}

This report was prepared as an account of work sponsored by an agency of the United States Government. Neither the United States Government nor any agency thereof, nor any of their employees, makes any warranty, express or implied, or assumes any legal liability or responsibility for the accuracy, completeness, or any third party's use or the results of such use of any information, apparatus, product, or process disclosed, or represents that its use would not infringe privately owned rights. Reference herin to any specific commercial product, process, or service by trade name, trademark, manufacturer, or otherwise, does not necessarily constitute or imply its endorsement, recommendation, or favoring by the Unites States

Government or any agency thereof or its contractors or subcontractors. The views and opinions of authors expressed herein do not necessarily state or reflect those of the United States Government or any agency thereof.

This report has been reproduced from the best available copy.

Printed in the United States of America 


\title{
The effect of high-level waste glass composition on spinel liquidus temperature
}

Pavel Hrma, ${ }^{*}, \mathrm{a}, \mathrm{b}$ Brian J Riley, ${ }^{\mathrm{a}}$ Jarrod V Crum, ${ }^{\mathrm{a}}$ Josef Matyas ${ }^{\mathrm{a}}$

${ }^{a}$ Pacific Northwest National Laboratory (PNNL), Richland, Washington 99354, USA

${ }^{b}$ Division of Advanced Nuclear Engineering, Pohang University of Science and Technology, Pohang, Republic of Korea

\begin{abstract}
Spinel crystals precipitate in high-level waste glasses containing $\mathrm{Fe}, \mathrm{Cr}, \mathrm{Ni}, \mathrm{Mn}, \mathrm{Zn}$, and $\mathrm{Ru}$. The liquidus temperature $\left(T_{L}\right)$ of spinel as the primary crystallization phase is a function of glass composition, and the spinel solubility $\left(C_{0}\right)$ is a function of both glass composition and temperature $(T)$. Previously reported models of $T_{t}$ as a function of composition are based on $T_{L}$ measured directly, which requires laborious experimental procedures. Viewing the curve of $c_{0}$ versus $T$ as the liquidus line allows a significant broadening of the composition region for model fitting. This paper estimates $T_{L}$ as a function of composition based on $c_{0}$ data obtained with the X-ray diffraction technique.
\end{abstract}

Key words: waste glass; spinel; liquidus temperature;

\section{Introduction}

High-level nuclear waste $\left(\mathrm{HLW}^{* *}\right)$ contains 40 to 60 chemical elements. Borosilicate glass is a chemically durable waste form capable of dissolving HLW oxides and halides and keeping them immobilized as long as the radioactive components do not decay. Because of the large number of

\footnotetext{
" Corresponding author: pavelhrma@postech.ac.kr, phone: 82-54-279-9562, fax: 82-54-279-9559

**High-level waste is the highly radioactive waste material resulting from the reprocessing of spent nuclear fuel, including liquid waste produced directly in reprocessing and any solid material derived from such liquid waste that contains fission products in sufficient concentrations; and other highly radioactive material that is determined, consistent with existing law, to require permanent isolation.
} 
components and a large compositional variability, where several hundreds of batches of different composition are anticipated for Hanford (Washington, USA) alone, mathematical models are indispensable for relating key properties to HLW glass composition such as viscosity, electrical conductivity, and chemical durability. The liquidus temperature $\left(T_{L}\right)$ of the primary crystalline phase is one of such properties, and upon vitrification spinel is the primary crystalline phase of most U.S. wastes from Pu production. Spinel crystals easily form during waste glass melting and exist in the melt at relatively high temperatures, at which they can interfere with melter operation [[1]-[24]]. Several studies were performed to obtain the liquidus temperature $\left(T_{t}\right)$ of spinel as a function of glass composition [[1],[2],[4],[8],[10],[12],[22]].

The experimental determination of $T_{L}$ is based on the identification of the highest temperature at which spinel can exist in glass at equilibrium. Spinel crystals are detected in quenched melts optically or with X-ray diffraction (XRD) $[[18],[25][26]]$. Both techniques require multiple melts and laborious sample preparation. Moreover, measuring $T_{L}$ poses numerous experimental difficulties including the control of redox reactions, glass homogeneity, and sample volatility [[4]]. The method based on differential scanning calorimetry is ruled out by the very low fraction of spinel precipitated (several mass $\%$ ) and the low thermal effect of the diffusion-controlled process of spinel crystallization.

In contrast with the time-consuming and laborious direct methods for measuring $T_{L}$, the experimental determination of the spinel solubility $\left(c_{0}\right)$ is relatively easy. Determining $c_{0}$ as a function of glass composition and temperature only requires quantitative XRD on specimens heat treated at various temperatures below $T_{L}$ that are doped with a known standard. While the direct method determines $T_{L}$ via extrapolation of the $c_{0}$ versus temperature $(T)$ function to $c_{0}=0$, this study estimates the $T_{L}$ of glasses from each $c_{0}(T)$ data point. It is based on the simple idea that the temperature at which the $c_{0}$ was obtained is the liquidus temperature of the matrix glass [[27]]. Since the matrix glass composition changes as spinel precipitates, the composition region for model fitting significantly broadens without 
the necessity of making the corresponding glasses and the separate laborious determination of $T_{L}$ for each. Moreover, having a $c_{0}$ data set per glass provides an opportunity to detect sample alterations caused by volatility, redox, and/or crystallization upon cooling. These effects are not easily observed when a single value is determined by optical measurements.

Although the idea of using $c_{0}$ data for $T_{L}$ determination appears simple, it faces its own challenge when applied to spinel. Spinels that precipitate in $\mathrm{HLW}$ glasses are solid solutions in the form $\mathrm{A}^{2+} \mathrm{B}^{3+}{ }_{2} \mathrm{O}_{4}$, containing $\mathrm{Cr}^{3+}, \mathrm{Fe}^{2+/ 3+}, \mathrm{Ni}^{2+}, \mathrm{Mn}^{2+/ 3+}$, and $\mathrm{Zn}^{2+}$ plus minor components, such as $\mathrm{Al}^{3+}, \mathrm{Ru}^{4+}$, and $\mathrm{Rh}^{3+}$. Oxides of these elements can be combined to make various spinel types. Thus, oxides of $\mathrm{Fe}, \mathrm{Cr}$, and $\mathrm{Ni}$ can be combined into four spinel end members: trevorite $\left(\mathrm{NiFe}_{2} \mathrm{O}_{4}\right)$, nichromite $\left(\mathrm{NiCr}_{2} \mathrm{O}_{4}\right)$, chromite $\left(\mathrm{FeCr}_{2} \mathrm{O}_{4}\right)$, and magnetite $\left(\mathrm{Fe}_{3} \mathrm{O}_{4}\right)$ with complete solid solutions existing between all. Various reports show that spinel composition changes with both glass composition and temperature $[[4],[28],[29]]$ and may not be uniform within the crystals because of changes in melt composition and redox [[12]]. The authors are not aware of any systematic study relating spinel composition to the conditions of crystal formation.

Because the composition of the matrix glass at equilibrium with spinel depends on spinel composition, the lack of precise knowledge of spinel composition complicates our task of obtaining $T_{L}$ as a function of glass composition. We circumvent this obstacle by either (1) assuming that spinel composition does not change with experimental variables (this approximation is good for small composition regions) or (2) by constructing simple rules for estimating spinel composition based on the content of spinel oxides in glass.

Several studies investigated spinel solubility in HLW glasses [[5],[9],[22],[30]-[33]]. Here we use two data sets, one by Schweiger et al. [[22]] and the other by Matyas et al. [[33]]. In both studies, glass samples were heat treated at various temperatures until the phase equilibrium was established. The mass fraction of spinel in the samples was measured with XRD. Both studies increased the precision of $c_{0}$ values with advanced XRD equipment and analysis software. 


\section{Theory}

At phase equilibrium between the melt and the primary crystalline phase, the crystals are surrounded with the matrix glass of a uniform composition. The content and composition of both the matrix glass and the crystalline phase are related to the composition of the original glass (before the crystals were formed) via the $i$-th component mass balance equation, also known as the lever rule:

$$
g_{i}^{0}=\left(1-c_{0}\right) g_{i}+c_{0} s_{i}
$$

where $g_{i}$ is the $i$-th component mass fraction in the matrix glass at equilibrium with spinel, $g_{i}^{0}$ is the $i$-th component mass fraction in the original glass with no spinel, $c_{0}$ is the equilibrium mass fraction of spinel phase in the mixture (of spinel and matrix glass), and $s_{i}$ is the $i$-th component mass fraction in spinel.

The glass composition region in the composition space has as many dimensions as the number of components that are considered influential. Because the fractions of all components sum to 1 , the large number of "crowded" components results in relatively narrow ranges of individual components. This situation favors approximating property-composition relationship with simple functions, such as first- or second-order polynomials. Hence, in spite of the general complexity of phase diagrams, the liquidus hypersurface for spinel is nearly flat within the composition region of HLW glasses [[4],[19]]. This "simplicity of complexity" allows us to postulate the relationship

$$
T_{L}^{0}=\sum_{i=1}^{N} T_{i} g_{i}^{0}
$$


where $T_{L}^{0}$ is the liquidus temperature and $T_{i}$ is the $i$-th component liquidus temperature coefficient. Similar relationships have been applied to the liquidus for sufficiently small composition regions of waste glasses and commercial glasses with various primary crystalline phases [[35]--[36]].

When the glass is allowed to reach phase equilibrium at $T<T_{L}$ and spinel is the only crystalline phase present in the melt, the temperature becomes a liquidus temperature for the matrix glass from which the spinel precipitated. This follows from the definition of $T_{L}$ as the maximum temperature at which the glass is at equilibrium with the primary crystalline phase. Suppose we remove spinel from the matrix melt, for example, by allowing it to settle, thus separating it from the matrix glass. From the spinel-free matrix melt, we can precipitate more spinel by decreasing the temperature. This spinel will dissolve completely by returning to the original heat-treatment temperature. Consequently, the $T_{L}$ of the matrix glass will be given by the formula

$$
T_{L}=\sum_{i=1}^{N} T_{i} g_{i}
$$

with the same component coefficients as in Eq. (1) and $T_{L}$ being identical to the heat-treatment temperature. Substituting for $g_{i}$ from Eq. (1) into (3), we obtain

$$
T_{L}=\frac{\sum_{i=1}^{N} T_{i} g_{i}^{0}-c_{0} \sum_{i=1}^{N} T_{i} s_{i}}{1-c_{0}}
$$

Provided that both $c_{0}$ versus $T$ data and the spinel composition data are available, the $T_{i}$ values can be computed by fitting Eq. (4) to these data. The needed $c_{0}$ versus $T$ data can be obtained with XRD. Crystal composition is obtainable with scanning electron microscopy and energy dispersive spectroscopy 
(SEM-EDS) or by chemical analysis if clean crystals isolated from the glass phase that can be dissolved in acid. If the spinel composition data are not available, as is the case in our study, we can still estimate the $T_{i}$ values by either treating $s_{i}$ as a set of fitting coefficients or approximating $s_{i}$ with simple rules specified below (Section 4).

\section{Experimental data}

The test glasses in the Schweiger et al. study [[22]] were designed as one-component-at-a-time variations of a baseline glass, whose composition is in Table 1. The components marked bold in the table were varied while all other components were kept at the same proportions as in the baseline glass. The composition variations for glasses with spinel primary phase are shown in Table 2 . The measured $c_{0}$ values for the test glasses heated at a various temperatures, too numerous to be reproduced in this paper, are listed in [[22]]. For illustration, Fig. 1 displays the spread of $c_{0}$ values as plotted against the undercooling below the optically determined $T_{L}$. Fig. 2 shows the ratio of the sum of $\mathrm{NiO}$ and $\mathrm{Cr}_{2} \mathrm{O}_{3}$ fraction in the original glass to the spinel fraction in the heat treated glass, i.e., $\left(g_{n}{ }^{0}+g_{c}{ }^{0}\right) / c_{0}$, as a function of $T_{L}^{o}-T$.

In a separate study, Matyas et al. [[33]] prepared eight simulated nuclear waste glasses. Each of the test glasses presented a compositional variation from a baseline glass containing 28 components. The varied components were $\mathrm{Al}_{2} \mathrm{O}_{3}, \mathrm{Cr}_{2} \mathrm{O}_{3}, \mathrm{Fe}_{2} \mathrm{O}_{3}, \mathrm{Li} 2 \mathrm{O}, \mathrm{NiO}$, and $\mathrm{RuO}_{2}$. The remaining 22 components were kept in the same proportions as in the baseline glass. Tables $3 \mathrm{a}$ and $3 \mathrm{~b}$ list the compositions of glasses in two alternative ways, one with simple oxides $\mathrm{NiO}, \mathrm{Cr}_{2} \mathrm{O}_{3}$, and $\mathrm{Fe}_{2} \mathrm{O}_{3}$ and the other in terms of spinels $\mathrm{NiFe}_{2} \mathrm{O}_{4}, \mathrm{NiCr}_{2} \mathrm{O}_{4}$, and $\mathrm{Fe}_{3} \mathrm{O}_{4}$. Note that expressing a part of the $\mathrm{Fe}_{2} \mathrm{O}_{3}$ content in terms of $\mathrm{FeO}$ changes mass fractions of the remaining components. The mass fractions of the remaining components are grouped into one component called "Others," presented in Table 4. Table 5 lists the $c_{0}$ versus $T$ data 
(Matyas et al. [[33]] did not obtain $c_{0}$ versus $T$ data for the baseline glass but did measure the $T_{L}^{0}$ of glasses by optical method and the results were close to those measured with XRD).

\section{Spinel composition}

Neither Schweiger et al. [[22]] nor Matyas et al. [[33]] report spinel composition. For simplicity, we considered spinel in glass as composed from three species, $\mathrm{Cr}_{2} \mathrm{O}_{3}, \mathrm{NiO}$, and $\mathrm{Fe}_{2} \mathrm{O}_{3}$, disregarding other possible constituents such as $\mathrm{MnO}, \mathrm{Mn}_{2} \mathrm{O}_{3}, \mathrm{ZnO}$, noble metal oxides, etc. To compensate for the lack of spinel composition data, we first assumed that spinel composition was independent of the glass composition and undercooling.

The attempt to obtain both the $T_{s}$ and a single spinel composition by fitting Eq. (4) to data worked for the relatively small composition region of glasses tested by Matyas et al. [[33]] but failed for a significantly larger composition region investigated by Schweiger et al. [[22]] (Fig. 3). In the case of Schweiger et al. [[22]] data, least-squares optimization resulted in negative fractions of $\mathrm{NiO}$ and $\mathrm{Cr}_{2} \mathrm{O}_{3}$ in the glass matrix, and when the negative fractions were eliminated by imposing constraints, the correlation was unacceptably poor. Attempts to obtain $s_{i}$ as a first-order polynomial function of glass composition and temperature by means of least-squares fitting appeared overparameterized. As a possible alternative, we estimated spinel composition by means of simple rules (stated below) that are based on empirical observations and the notion of partition factors.

Both phases, molten glass and spinel, are solutions of oxides. At equilibrium, the $i$-th component partition factors, defined as

$$
f_{i}=\frac{s_{i}}{g_{i}}
$$


are functions of mixture composition and temperature. According to Annamalai et al. [[28]], the $\mathrm{Cr}_{2} \mathrm{O}_{3}$ fraction is 130 to 220 times higher in spinel than in the matrix glass; for $\mathrm{NiO}$, the corresponding values are 10 to 50 . For example, if 3 mass $\%$ spinel precipitates in a glass containing 1.2 mass $\% \mathrm{Cr}_{2} \mathrm{O}_{3}$, and assuming that $f_{i} \approx 200$, the estimated fraction of $\mathrm{Cr}_{2} \mathrm{O}_{3}$ in the matrix glass is 0.17 mass $\%$ and the fraction of $\mathrm{Cr}_{2} \mathrm{O}_{3}$ in the spinel is 34 mass\%.

Combining Eqs. (1) and (5), we obtain for the matrix glass composition the equation

$$
g_{i}=\frac{g_{i}^{0}}{1+\left(f_{i}-1\right) c_{0}}
$$

We used this equation to estimate the minimum remaining fractions of $\mathrm{Cr}_{2} \mathrm{O}_{3}$ and $\mathrm{NiO}$ in the matrix glass in equilibrium with large fractions of spinel.

The relative values of $f_{i}$ for $\mathrm{Cr}_{2} \mathrm{O}_{3}$ and $\mathrm{NiO}$ reported by Annamalai et al. [[28]] are in accordance with the observation that the $T_{i}$ values of major spinel-forming components decrease in the order $\mathrm{Cr}_{2} \mathrm{O}_{3}$ $>\mathrm{NiO}>\mathrm{Fe}_{2} \mathrm{O}_{3}$. For example, Vienna et al. [[4]] obtained the following values of $T_{\mathrm{s}} \mathrm{s}$ in terms of mole fractions of cations [or, equivalently, oxides expressed as $\mathrm{CrO}_{1.5}, \mathrm{FeO}_{1.5}$, etc.; note that this way of expressing glass composition changes the mass fraction values, and thus the $T_{\mathrm{s}} \mathrm{s}$ in Eq. (2)]: $T_{\mathrm{cr}}=3.21 \times$ $10^{4} \mathrm{~K}, T_{\mathrm{Ni}}=1.41 \times 10^{4} \mathrm{~K}, T_{\mathrm{Fe}}=4.01 \times 10^{3} \mathrm{~K}$. Provided that all these three species are present in the glass, one can conjecture that spinel nucleates as nichromite, then continues to grow first as trevorite or chromite and then as magnetite, while blending these elementary spinels into a solid solution.

Based on these observations, one can hypothesize that one of the following four cases will occur:

1. If the maximum $f_{i}$ of $\mathrm{Cr}_{2} \mathrm{O}_{3}$ is reached to form nichromite, and $\mathrm{NiO}$ is still available in the matrix glass, trevorite forms until either the maximum $f_{i}$ of $\mathrm{NiO}$ is reached, or $c_{0} \approx c_{N}+c_{T}$, where $c_{N}$ and $c_{T}$ are the mass fractions of nichromite and trevorite, respectively. 
2. If the maximum $f_{i}$ of $\mathrm{NiO}$ is reached to form nichromite, and $\mathrm{Cr}_{2} \mathrm{O}_{3}$ is still available in the matrix glass, chromite forms until either the maximum $f_{i}$ of $\mathrm{Cr}_{2} \mathrm{O}_{3}$ is reached, or $c_{0} \approx c_{N}+c_{C}$, where $c_{C}$ is the mass fraction chromite in spinel.

3. If the maximum $f_{\underline{i}}$ of both $\mathrm{Cr}_{2} \mathrm{O}_{3}$ and $\mathrm{NiO}$ is reached, then magnetite forms until $c_{0}=c_{N}+c_{T}+c_{M}$, where $c_{M}$ is the mass fraction of magnetite in spinel. It is assumed that enough $\mathrm{Fe}_{2} \mathrm{O}_{3}$ is present in the glass to make this possible.

4. If $c_{0} \approx c_{N}$, nearly all spinel is assumed to be of nichromite composition and the fractions of other simple spinels are neglected, i.e., $c_{T} \approx c_{C} \approx c_{M} \approx 0$.

Accordingly, depending on the relative proportions of $\mathrm{Cr}_{2} \mathrm{O}_{3}$ and $\mathrm{NiO}$ in glass, and assuming that a sufficient amount of $\mathrm{Fe}_{2} \mathrm{O}_{3}$ is present while disregarding any spinel components other than $\mathrm{NiO}, \mathrm{Cr}_{2} \mathrm{O}_{3}$, and $\mathrm{Fe}_{2} \mathrm{O}_{3}$, spinel can be nearly all nichromite $\left(c_{0} \approx c_{N}\right)$, a solid solution of nichromite and trevorite $\left(c_{0} \approx\right.$ $\left.c_{N}+c_{T}\right)$, a solid solution of nichromite and chromite $\left(c_{0} \approx c_{N}+c_{C}\right)$, or a solid solution of nichromite, chromite and magnetite $\left(c_{0}=c_{N}+c_{T}+c_{M}\right)$. This scheme presents a simplification because spinel crystals typically contain all three major oxides, i.e., $\mathrm{Fe}_{2} \mathrm{O}_{3}, \mathrm{NiO}$, and $\mathrm{Cr}_{2} \mathrm{O}_{3}$. As Table 6 shows, this oversimplification affects a relatively small number of data (13 out of 129). On the other hand, large portions of data are constrained by the maximum values of the $f_{\mathrm{s}}$.

For the fitting, Schweiger et al. [[22]] data were arranged in one of two different ways. For Model 1 , the 129 data points with $c_{0}>0$ were joined with 35 data points that had optically determined $T_{L}$ values; for these data, $c_{0}=0$, and thus, by Eq. (1), $g_{i}=g_{i}^{0}$. Model 2 did not use optically determined $T_{L} \mathrm{~s}$ and was based solely on XRD data, i.e., those with $c_{0}>0$. Fitting Eq. (3) to $\left(T, g_{i}\right)$ data, with $g_{i}$ values, calculated by Eq. (1) as $g_{i}=\left(g_{i}^{0}-c_{0} s_{i}\right) /\left(1-c_{0}\right)$, we obtained the liquidus temperature coefficients, $T_{i}$. The values of $s_{i}$ were obtained by applying stoichiometry to the $c_{1}$ estimates $(I \equiv N, C, T, M$, where the subscripts denote nichromite, chromite, trevorite, and magnetite, respectively). Afterwards, $g_{i}$ and $s_{i}$ 
values for $\mathrm{Cr}_{2} \mathrm{O}_{3}$ and $\mathrm{NiO}$ were determined using Eqs. (5) and (6) for all data where this scheme would result in $f_{\mathrm{i}} \mathrm{s}$ larger than the maximum admissible values, i.e., 200 and 50 for $\mathrm{Cr}_{2} \mathrm{O}_{3}$ and $\mathrm{NiO}$, respectively.

\section{Results}

5.1 Models based on Schweiger et al. [[22]] data

Data for which $\left|T_{L}-T\right|>60 \mathrm{~K}$ (here $T$ is the test temperature and $T_{L}$ is the estimated liquidus temperature for the matrix glass) were considered outliers and were not included in model fitting-see the cumulative histogram in Fig. 4. The number of outliers was 11 in Model 1 (out of 164 data points; 2 were optical $T_{L}$ values) and 9 in Model 2 (out of 129 data points). The outliers could indicate erroneous data, but they also are indicative of curved areas of the liquidus surface away from the region in which Eq. (3) is applicable.

Table 7 lists the $T_{i}$ values and compares them with the $T_{\mathrm{S}}$ s previously published. Not surprisingly, the $R^{2}$ is higher for Model $2(0.967)$ than for Model $1(0.948)$; as expected, $R^{2}$ values are lower when data for $c_{0}=0$ and $c_{0}>0$ are treated separately (Fig. 5). However, $T_{L}$ values estimated with Model 1 and Model 2 differ little (Fig. 6).

The effect of various components on the $T_{L}$ can be judged by the change of $T_{L}$ when replacing the $\mathrm{SiO}_{2}$ with an $i$-th component. As the $T_{i}$ coefficients listed in Table 7 for Model 1 and 2 imply, 0.1 mass $\%$ of $\mathrm{Cr}_{2} \mathrm{O}_{3}$, when added at the expense of $\mathrm{SiO}_{2}$, changes $T_{L}$ by $29-38 \mathrm{~K}, \mathrm{NiO}$ by $\sim 15 \mathrm{~K}, \mathrm{Fe}_{2} \mathrm{O}_{3}$ by $\sim 2 \mathrm{~K}, \mathrm{Al}_{2} \mathrm{O}_{3}$ by $\sim 2 \mathrm{~K}$, and $\mathrm{Li}_{2} \mathrm{O}$ by -4 to $-3 \mathrm{~K}$. The maximum content of $\mathrm{RuO}_{2}$ in the test glasses was 0.087 mass\% (Table 1). Adding this amount to a Ru-free glass leads to a $T_{L}$ increase of $\sim 14 \mathrm{~K}$.

5.2 Models based on Matyas et al. [[33]] data

Whereas the large composition region used by Schweiger et al. [[22]] did not allow a reasonable fit while assuming a constant spinel composition, this approximation worked for the smaller composition 
region investigated by Matyas et al. [[33]] (Fig. 3). We fitted Equation (4) to data listed in Tables 3 and 5 by optimizing, with least squares optimization, the values of $T_{i}$ and the $s_{i} T_{i}$ product. Two data points were not used for calculation: Ni1.5/Al10 and Ni1.5/Fe17.5, both at $850^{\circ} \mathrm{C}$; see the italicized numbers in Table 5.

Table 8 shows $T_{i}$ and Table 9 (the two right columns) $s_{i}$ values for two fits, one based on simple oxides (Table 3a) and the other on Ni-Cr-Fe spinels (Table 3b). Judging from the high value of the correlation coefficient, $R^{2}=0.983$, both fits are excellent in spite of the simplifying approximations. Fig. 7 compares the estimated $T_{L}$ with the temperature at which the glasses were equilibrated. As the right plot in Fig. 7 shows, the way in which the glass composition is expressed does not make a difference for the estimated $T_{i}$.

\section{Discussion}

\subsection{Possible biases}

As the comparison of $T_{L}$ estimates (Fig. 5, right, and Fig. 6) indicate, data based on XRD appear biased when plotted against data based on the optical method. In fact, various biases exist:

1. XRD extrapolation bias is caused by two factors:

a. Low $c_{0}$ values that occur as $T \rightarrow T_{L}$ are not measured sufficiently accurately by XRD, because of detection limits and a low signal to noise ratio. Thus, low fractions of crystals may be undetected by XRD.

b. As $T \rightarrow T_{L}$, the slope, $\mathrm{d} c_{0} / \mathrm{d} T$, can dramatically increase, leading to overestimated $T_{L}$.

2. The optical method can also be biased by various means:

a. Crystals can form above $T_{L}$ because of concentration fluctuation, minor inhomogeneities, melt volatilization, or interaction between the melt and the crucible wall. 
b. Crystals may not be detected below $T_{L}$ because of the lack of nucleation (unlikely in the case of spinel), because tiny crystals can be missed, or because crystals are present in the bulk but absent in the thin section used for optical microscopy.

3. Sample cooling can also lead to misleading results:

a. Slow-nucleating and slow-growing crystals can result in a lower value of measured $c_{0}$.

b. New crystals may form after the heat treatment during quenching even in melts heat treated at temperatures above $T_{L}$.

Our method of obtaining $T_{L}$ versus composition from $c_{0}$ data rests on the assumption that the matrix glass has a uniform composition that is in equilibrium with the crystalline phase, i.e., that concentration gradients are absent in the matrix glass. A presence of concentration gradients would imply that the $g_{i}$ values in Eq. (1) are average compositions of matrix glasses, bringing an additional uncertainty to the $T_{i}$ coefficients listed in Tables 7 and 8 . The validity of the glass uniformity assumption can be tested by direct measurements or by preparing matrix glass and checking its $T_{L}$.

\subsection{Spinel composition uncertainty}

Table 9 and Fig. 8 summarize estimated spinel compositions for both studies. The fitted composition based on Matyas et al. [[33]] data is mainly a solution of trevorite and magnetite with chromite as a minor component. In terms of mole fractions of basic spinels, the fitted spinel consisted of 46-49 mol\% trevorite, 47-49 mol\% magnetite, and 5 mol\% nichromite. This can be compared with the composition of spinel crystals that settled in Ni1.5 glass [[37]] and examined with SEM-EDS. In the atomic fractions of cations, that spinel contained $0.614 \mathrm{Fe}, 0.348 \mathrm{Ni}, 0.022 \mathrm{Cr}$, and $0.016 \mathrm{Mn}$; omitting $\mathrm{Mn}$, it is equivalent to 97 mol\% trevorite and $~ 3$ mol\% chromite.

For the Schweiger et al. [[22]] study, spinel composition varies considerably. Nichromite is the dominant phase followed by trevorite, while chromite and magnetite are minor ingredients, indicating a 
bias in favor of chromite. The difference in the temperature ranges between the studies could lead to differences in spinel composition: the range of temperatures in the Matyas et al. [[33]] study (844$1150^{\circ} \mathrm{C}$ ) was narrower and the maximum was shifted to lower temperature than in the Schweiger et al. [[22]] study $\left(844-1431^{\circ} \mathrm{C}\right)$. One can speculate that the lower temperature favors the formation of magnetite.

Fortunately, uncertainty in spinel composition estimates did not compromise agreement between measured and estimated $T_{L}$. Because values of $T_{i}$ and $s_{i}$ occur in Eq. (4) as a sum of $T_{i} s_{i}$ products, a compensation effect between these values possibly offsets the uncertainty in $s_{i}$ estimates.

\subsection{Spinel equilibrium fraction}

Using the $T_{i}$ and $s_{i}$ coefficients, we can estimate $c_{0}$ versus $T$ curves for glasses within the composition regions of the test glasses studied. After rewriting Equation (4) as

$$
T_{L}=\frac{T_{L}^{0}-c_{0} T_{S}}{1-c_{0}}
$$

where $T_{L}^{0}$ is defined by Equation (2) and $T_{S}=\sum_{i=1}^{N} T_{i} s_{i}$, we obtain for $c_{0}$ the expression

$$
c_{0}=\frac{T_{L}^{0}-T_{L}}{T_{S}-T_{L}}
$$

By replacing the $T_{L}$ symbol with $T$, the temperature at which the melt was equilibrated, we can recover the original data. Moreover, based on $T_{i}$ values and the knowledge or a reasonable estimate of 
the crystalline phase composition, we can use Eq. (6) to estimate the "solubility limit" of crystal-forming components in glasses within the composition region of the model validity.

Fig. 9 demonstrates good agreement between the calculated curves and Matyas et al. [[33]] data listed in Table 5. Both $T_{L}^{0}$ and $T_{S}$ values were obtained using $T_{i}$ and $s_{i}$ values listed in Tables 8 and 9 (simple oxides). The $T_{L}^{0}$ values are listed in Table 10 and $T_{S}=6528^{\circ} \mathrm{C}$. For small $T_{L}$ values, Eq. (6) yields the theoretical maximum spinel content in the glass as $c_{M}=T_{L}^{0} / T_{S}$, where the temperatures are in $\mathrm{K}$. The $c_{M}$ values are shown in Table 10 . These values are 15 to $32 \%$ higher than the sum, $c_{\text {max }}$, of $\mathrm{NiFe}_{2} \mathrm{O}_{4}$, $\mathrm{NiCr}_{2} \mathrm{O}_{4}$, and $\mathrm{Fe}_{3} \mathrm{O}_{4}$ mass fractions listed in Table $3 \mathrm{~b}$. This indicates that the linear model cannot be extrapolated to temperatures much lower than $850^{\circ} \mathrm{C}$, even though the spinel contains some additional components ( $2-5 \%$ of the glass).

\subsection{Composition region extension}

As has been stated in the Introduction, the composition region of the $T_{L}$ model validity broadens when $c_{0}$ versus $T$ data are used for model fitting. Table 11 compares the composition region of the matrix glasses with the composition region of the original test glasses, showing that the ranges of the spinel forming components substantially increased ( $\mathrm{NiO}$ by $18 \%, \mathrm{Cr}_{2} \mathrm{O}_{3}$ by $114 \%$, and $\mathrm{Fe}_{2} \mathrm{O}_{3}$ by $84 \%$ ).

In comparison with the optical method [[22]], the composition ranges covered by the XRD extrapolation method increased by 1 to $5 \%$ and the temperature range of $T_{L}$ increased from 1021$1363^{\circ} \mathrm{C}$ of optically determined $T_{L}$ to $843-1396^{\circ} \mathrm{C}$ of Model 1 and $836-1493^{\circ} \mathrm{C}$ of Model 2.

\section{Conclusions}

A simple component mass balance allows the spinel content $\left(c_{0}\right)$ versus temperature $(T)$ curve to be viewed as the liquidus line, thus significantly broadening the composition region for model fitting. Using published $c_{0}(T)$, composition coefficients for $T_{L}$ and spinel composition were estimated by least-squares 
optimization. Although the model is based on various simplifying assumptions, it fits data reasonably well.

\section{Acknowledgments}

The authors gratefully acknowledge the financial support of the U.S. Department of Energy Federal Project Office Engineering Division for the Hanford Tank Waste Treatment and Immobilization Plant. Pavel Hrma was supported also by the World Class University program through the National Research Foundation of Korea funded by the Ministry of Education, Science and Technology (R31-30005). The authors greatly appreciate Albert Kruger for his assistance and guidance. Pacific Northwest National Laboratory is operated by Battelle Memorial Institute for the U.S. Department of Energy under contract DE-AC05-76RL01830.

\section{References}

[1] D.-S. Kim, P. Hrma, "Models for liquidus temperature of nuclear waste glasses," in Proc. Environ. Waste Manag. Issues Ceram. Ind. II, American Ceramic Society (1994).

[2] M. Mika, M.J. Schweiger, J.D. Vienna, P. Hrma, “Liquidus temperature of spinel precipitating high-level waste glasses," in Proc. Sci. Basis Nucl. Waste Manag. XX, 465, 71-78 (1997).

[3] P. Hrma, J.D. Vienna, J.V. Crum, G.F. Piepel, “Liquidus temperature of high-level waste borosilicate glasses with spinel primary phase," In Proc. Sci. Basis for Nucl. Waste Manag. XXIII, Materials Research Society 608, 671676 (2000).

[4] J.D. Vienna, P. Hrma, J.V. Crum, M. Mika, “Liquidus temperature-composition model for multicomponent glasses in the $\mathrm{Fe}, \mathrm{Cr}, \mathrm{Ni}$, and $\mathrm{Mn}$ spinel primary phase field, J. Non-Cryst. Solids, $292(1-3)(2001) 1-24$. 
[5] P. Izak, P. Hrma, B.W. Arey, T.J. Plaisted, “Effect of feed melting, temperature history, and minor component addition on spinel crystallization in high-level waste glass," J. Non-Cryst. Solids, $289(1-3)(2001) 17-29$

[6] P. Hrma, J. Alton, J. Klouzek, J. Matyas, M. Mika, L. Nemec, T.J. Plaisted, P. Schill, M. Trochta, "Increasing High-Level Waste Loading in Glass without Changing the Baseline Melter Technology," Waste Management '01, University of Arizona, Tucson, Arizona, (2001).

[7] J. Matyas, J. Klouzek, L. Nemec, M. Trochta, "Spinel settling in HLW melters," Proc. Int. Conf. Radioact. Waste Manage. Environ. Remed. ICEM, 3, 1787-1792 (2001).

[8] P. Hrma, P. Izak, J.D. Vienna, M.-L. Thomas, G.M. Irwin, “Partial molar liquidus temperatures of multivalent elements in multicomponent borosilicate glass," Phys. Chem. Glasses (UK), 43(2) (2002) 119-127.

[9] J. Alton, T.J. Plaisted, P. Hrma, "Dissolution and growth of spinel crystals in a borosilicate glass," J. Non-Cryst. Solids, 311(1) (2002) 24-35.

[10] B.K. Wilson, P. Hrma, J. Alton, T.J. Plaisted, J.D. Vienna, “The effect of composition on spinel equilibrium and crystal size in high-level waste glass," J. Mater. Sci., 37(24) (2002) 5327-5331.

[11] M. Jiricka, L. Nemec, "Spinel crystal distribution and settling in a high-level waste melter working as a perfect mixer Part 2. Results of calculations," Ceram. Silikaty, 46(4) (2002) 127-132.

[12] M. Jiricka, P. Hrma, J.D. Vienna, "The effect of composition of spinel crystals equilibrium in lowsilica high-level waste glasses," J. Non-Cryst. Solids, 319(3) (2003) 280-288.

[13] J.G. Reynolds, "Spinel structure and liquidus temperature relationships in nuclear waste glasses," J. Mater Sci., 40(15) (2005) 3987-3991.

[14] J.D. Vienna, T.B. Edwards, J.V. Crum, D.-S. Kim, D.K. Peeler, “Liquidus temperature and one percent crystal content models for initial Hanford HLW glasses," in: Proc. Environ. Issues Waste Manage. Tech. Ceram. Nucl. Ind. X-Ceram. Trans., 168, 133-140 (2005). 
[15] C.M. Jantzen, K.G. Brown, “Predicting the spinel-nepheline liquidus for application to nuclear waste glass processing. Part I. Primary phase analysis, liquidus measurement, and quasicrystalline approach," J. Am. Ceram. Soc., 90(6) (2007) 1866-1879.

[16] C.M. Jantzen, K.G. Brown, “Predicting the spinel-nepheline liquidus for application to nuclear waste glass processing. Part II: quasicrystalline freezing point," J. Am. Ceram. Soc., 90(6) (2007) 1880-1891.

[17] W. Gong, W. Lutze, I.L. Pegg, “Testing and modelling the behaviour of platinoids during vitrification of high level radioactive waste: Part 4. Effect of spinel," Glass Technol. Euro. J. Glass Sci, Technol. Part A, 50(3) (2009) 151-164.

[18] J. Marra, S. Stefanovsky, V. Lebedev, D. Suntsov, "The results of testing to evaluate crystal formation and settling in the cold crucible induction melter," Proc. Int. Conf. Radioact. Waste Manage. Envir. Remed. ICEM'09, 1, 851-857 (2009).

[19] P. Hrma, "Crystallization During Processing of Nuclear Waste Glass,"J. Non-Cryst. Solids, 356(5254) (2010) 3019-3025.

[20] J. Matyas, J.D. Vienna, M.J. Schaible, C.P. Rodriguez, J.V. Crum, A.L. Arrigoni, R.M. Tate, Development of Crystal-Tolerant High-Level Waste Glasses, PNNL-20072 (2010) Pacific Northwest National Laboratory, Richland, WA.

[21] J. Matyas, J.D. Vienna, A. Kimura, M.J. Schaible, R.M. Tate, "Development of Crystal-Tolerant Waste Glasses." Chapter 5 in: K. Fox, E. Hoffman, N. Manjooran and G. Pickrell (Eds.), Advances in Materials Science for Environmental and Nuclear Technology: Ceramic Transactions, vol. 222, John Wiley \& Sons, Inc., Hoboken, NJ, (2010) pp. 41-51.

[22] M.J. Schweiger, B.J. Riley, J.V. Crum, P.R. Hrma, C.P. Rodriguez, B.M. Arrigoni, J.B. Lang, D.S. Kim, J.D. Vienna, F.C. Raszewski, D.K. Peeler, T.B. Edwards, D.R. Best, I.A. Reamer, W.T. Riley, P.T. 
Simmons, R.J. Workman, Expanded High-Level Waste Glass Property Data Development: Phase I, PNNL-17950, Pacific Northwest National Laboratory, Richland, WA, USA, 2011.

[23] J. Matyas, A.R. Huckleberry, C.P. Rodriguez, J.D. Vienna, and A.A. Kruger, "Empirical Model for Formulation of Crystal-Tolerant HLW Glasses." Accepted for publication in Ceramic Transactions (2012). PNNL-SA-83235, Pacific Northwest National Laboratory, Richland, WA. 2011.

[24] J. Matyas, A.R. Huckleberry, C.P. Rodriguez, J.B. Lang, A.T. Owen, A.A. Kruger, HLW Glass Studies: Development of Crystal-Tolerant HLW Glasses, PNNL-21308, Pacific Northwest National Laboratory, Richland, WA, 2012.

[25] B.J. Riley, P. Hrma, J.D. Vienna, M.J. Schweiger, C.P. Rodriguez, J.V. Crum, J.B. Lang, J.C. Marra, F.C. Johnson, D.K. Peeler, C. Leonelli, A.M. Ferrari, I. Lancellotti, J.-L. Dussossoy, R.J. Hand, J.M. Schofield, A.J. Connelly, R. Short, M.T. Harrison, “The Liquidus Temperature of Nuclear Waste Glasses: An International Round-Robin Study," Int. J. Appl. Glass Sci. 2(4), (2011) 321-333.

[26] ASTM-C1720-11. Standard Method for Determining Liquidus Temperature of Immobilized Waste Glasses and Simulated Waste Glasses, (2011) ASTM International, West Conshohocken, PA.

[27] P. Hrma, J.D. Vienna. "Relationship between Liquidus Temperature and Solubility," Ceram. Trans. 143 (2003) 159-167.

[28] S. Annamalai, H. Gan, M. Chaudhuri, W.K. Kot, I.L. Pegg, Spinel crystallization in HLW glass melts: Cation exchange systematics and the role of $\mathrm{Rh}_{2} \mathrm{O}_{3}$ in spinel formation, Environmental Issues and Waste Management Technologies IX, Ceram Trans. 155, (2004) 279-288.

[29] S. Annamalai, Thermodynamics and kinetics of spinel crystallization of near-liquidus crystalline phases in defense nuclear waste glass melts, Thesis, The Catholic University of America, Washington, DC, USA, 2007.

[30] J.G. Reynolds and P. Hrma, "The Kinetics of Spinel Crystallization from a High-Level Waste Glass," Mat. Res. Soc. Symp. Proc. 465, 261-268 (1997). 
[31] M. Mika, M. Patek, J. Maixner, S. Randakova, P. Hrma, "The Effect of Temperature and Composition on Spinel Concentration and Crystal Size in High-Level Waste Glass," The $8^{\text {th }}$ International Conference Proceedings (ICEM'01), Bruges, Belgium, 2001.

[32] T.J. Plaisted, J. Alton, B.K. Wilson, P. Hrma, “Effect of Minor Component Addition on Spinel Crystallization in Simulated High-Level Waste Glass," Ceram. Trans. 119 (2001) 317-325.

[33] J. Matyáš, A.R. Huckleberry, C.P. Rodriguez, J.B. Lang, A.T. Owen, A.A. Kruger, HLW Glass Studies: Development of Crystal-Tolerant HLW glasses, PNNL-21308, Pacific Northwest National Laboratory and U.S. Department of Energy Office of River Protection, Richland, WA, USA, 2012.

[34] Q. Rao, G.F. Piepel, P. Hrma, J.V. Crum, “Liquidus Temperatures of HLW Glasses with ZirconiumContaining Primary Crystalline Phases," J. Non-Cryst. Solids 220(1) (1997) 17-29.

[35] P. Hrma, D.E. Smith, J. Matyáš, J.D. Yeager, J.V. Jones, E.N. Boulos, “Effect of float glass composition on liquidus temperature and devitrification behavior," European Journal of Glass Science and Technology, Part B: Physics and Chemistry of Glasses 47(3) (2006) 64-76.

[36] L. Wondraczek, L. Beunet, “Liquidus prediction in multicomponent lithium alumosilicate glasses," J. Am. Ceram. Soc. 91(4) (2008) 1309-1311.

[37] J. Matyas, J.D. Vienna, M. Schaible, “Determination of Stokes shape factor for single particles an agglomerates," in: Advances in Materials Science for Environmental and Nuclear Technology II, S.K. Sundaram, T. Ohji, K.M. Fox, E. Hoffman (Eds.), Ceramic Transactions 227, 2011, pp. 195-203.

\section{Figure captions}

Fig. 1 Spinel mass fraction versus undercooling below optically determined $T_{L}$.

Fig. 2. Ratio of $\mathrm{NiO}+\mathrm{Cr}_{2} \mathrm{O}_{3}$ mass fractions in glass to $c_{0}$ versus undercooling below optically determined $T_{L} ;$ the trend line is a hyperbola $y=x_{0} / x$, where $y=\left(g_{n}{ }^{0}+g_{c}{ }^{0}\right) / c_{0}, x=T_{L}{ }^{0}-T$, and $x_{0}=180 \mathrm{~K}$. 
Fig. 3. Matrix glass component ranges for glasses varying the components shown based on data sets by Schweiger et al. [[22]] and Matyas et al. [[33]]

Fig. 4. Cumulative histogram of deviations between estimated $T_{L}$ and heat-treatment temperature (Model 1)

Fig. 5. Estimated $T_{L}$ versus test temperature (left) and optically measured $T_{L}$ (right)

Fig. 6. Estimated $T_{L}$, Model 2 versus Model 1

Figure 7. Estimated $T_{L}$ versus test temperature (left); comparison of $T_{L}$ estimates based on alternative ways of expressing glass composition (right)

Fig. 8. Spinel composition based on Schweiger et al. [[22]] data (Model 1) and Matyas et al. [[33]] data Fig. 9. Measured data and fitted lines for equilibrium spinel mass fraction [33] 
Table 1. Baseline glass composition in mass fractions [[22]]

\begin{tabular}{ll|ll|ll}
$\mathrm{Al}_{2} \mathbf{O}_{3}$ & 0.1000 & $\mathrm{MgO}$ & 0.0015 & $\mathbf{P d O}$ & 0.00009 \\
$\mathbf{B}_{2} \mathrm{O}_{3}$ & 0.1000 & $\mathbf{M n O}$ & 0.0200 & $\mathbf{R h}_{2} \mathbf{O}_{3}$ & 0.00003 \\
$\mathrm{BaO}$ & 0.0005 & $\mathrm{Na}_{2} \mathbf{O}$ & 0.1500 & $\mathbf{R u O}_{2}$ & 0.00018 \\
$\mathrm{Bi}_{2} \mathbf{O}_{3}$ & 0.0000 & $\mathrm{Nd}_{2} \mathrm{O}_{3}$ & 0.0007 & & \\
$\mathrm{CaO}$ & 0.0000 & $\mathrm{NiO}$ & 0.0100 & & \\
$\mathrm{CdO}$ & 0.0014 & $\mathbf{P}_{2} \mathbf{O}_{5}$ & 0.0125 & & \\
$\mathrm{Ce}_{2} \mathrm{O}_{3}$ & 0.0005 & $\mathrm{PbO}$ & 0.0037 & & \\
$\mathrm{Cr}_{2} \mathbf{O}_{3}$ & 0.0050 & $\mathrm{SiO}_{2}$ & 0.4333 & & \\
$\mathbf{F}$ & 0.0010 & $\mathrm{SO}_{3}$ & 0.0030 & & \\
$\mathrm{Fe}_{2} \mathbf{O}_{3}$ & 0.1000 & $\mathrm{SrO}$ & 0.0024 & & \\
$\mathbf{K}_{2} \mathbf{O}$ & 0.0000 & $\mathrm{TiO}_{2}$ & 0.0004 & & \\
$\mathrm{La}_{2} \mathrm{O}_{3}$ & 0.0007 & $\mathrm{ZnO}$ & 0.0006 & \\
$\mathrm{Li}_{2} \mathbf{O}$ & 0.0275 & $\mathrm{ZrO}_{2}$ & 0.0250 & &
\end{tabular}

Table 2. List of test glasses with component varied [[22]]

\begin{tabular}{llc|llc|llc} 
ID & Oxide & Mass fraction & $\mathrm{ID}$ & Oxide & Mass fraction & ID & Oxide & Mass fraction \\
\hline $\mathrm{Al}-06$ & $\mathrm{Al}_{2} \mathrm{O}_{3}$ & 0.0600 & $\mathrm{Cr}-02$ & $\mathrm{Cr}_{2} \mathrm{O}_{3}$ & 0.0200 & $\mathrm{Na}-20$ & $\mathrm{Na}{ }_{2} \mathrm{O}$ & 0.2000 \\
$\mathrm{Al}-15$ & $\mathrm{Al}_{2} \mathrm{O}_{3}$ & 0.1500 & $\mathrm{~F}-02$ & $\mathrm{~F}$ & 0.0200 & $\mathrm{Ni}-001$ & $\mathrm{NiO}$ & 0.0010 \\
$\mathrm{Al}-20$ & $\mathrm{Al}_{2} \mathrm{O}_{3}$ & 0.2000 & $\mathrm{Fe}-05$ & $\mathrm{Fe}_{2} \mathrm{O}_{3}$ & 0.0500 & $\mathrm{Ni}-02$ & $\mathrm{NiO}$ & 0.0200 \\
$\mathrm{~B}-05$ & $\mathrm{~B}_{2} \mathrm{O}_{3}$ & 0.0500 & $\mathrm{Fe}-15$ & $\mathrm{Fe}_{2} \mathrm{O}_{3}$ & 0.1500 & $\mathrm{P}-0$ & $\mathrm{P}_{2} \mathrm{O}_{5}$ & 0.0000 \\
$\mathrm{~B}-15$ & $\mathrm{~B}_{2} \mathrm{O}_{3}$ & 0.1500 & $\mathrm{Fe}-20$ & $\mathrm{Fe}_{2} \mathrm{O}_{3}$ & 0.2000 & $\mathrm{P}-025$ & $\mathrm{P}_{2} \mathrm{O}_{5}$ & 0.0250 \\
$\mathrm{~B}-20$ & $\mathrm{~B}_{2} \mathrm{O}_{3}$ & 0.2000 & $\mathrm{~K}-03$ & $\mathrm{~K}_{2} \mathrm{O}$ & 0.0300 & $\mathrm{Si}-30$ & $\mathrm{SiO}_{2}$ & 0.3000 \\
$\mathrm{Bi}-025$ & $\mathrm{Bi}_{2} \mathrm{O}_{3}$ & 0.0250 & $\mathrm{~K}-06$ & $\mathrm{~K}_{2} \mathrm{O}$ & 0.0600 & $\mathrm{Si}-37$ & $\mathrm{SiO}_{2}$ & 0.3700 \\
$\mathrm{Bi}-05$ & $\mathrm{Bi}_{2} \mathrm{O}_{3}$ & 0.0500 & $\mathrm{Li}-015$ & $\mathrm{Li} 2 \mathrm{O}$ & 0.0150 & $\mathrm{Si}-50$ & $\mathrm{SiO}_{2}$ & 0.5000 \\
$\mathrm{Ca}-035$ & $\mathrm{CaO}$ & 0.0350 & $\mathrm{Li}-04$ & $\mathrm{Li} 2 \mathrm{O}$ & 0.0400 & $\mathrm{Zr}-001$ & $\mathrm{ZrO}_{2}$ & 0.0010 \\
$\mathrm{Ca}-07$ & $\mathrm{CaO}$ & 0.0700 & $\mathrm{Mn}-01$ & $\mathrm{MnO}$ & 0.0010 & $\mathrm{Zr}-05$ & $\mathrm{ZrO}_{2}$ & 0.0500 \\
$\mathrm{Cr}-001$ & $\mathrm{Cr} \mathrm{O}_{2} \mathrm{O}_{3}$ & 0.0010 & $\mathrm{Mn}-04$ & $\mathrm{MnO}$ & 0.0400 & $\mathrm{NM}-0025$ & $\mathrm{NM}^{\mathrm{a}}$ & 0.0024 \\
$\mathrm{Cr}-012$ & $\mathrm{Cr}_{2} \mathrm{O}_{3}$ & 0.0120 & $\mathrm{Na}-10$ & $\mathrm{Na} 2 \mathrm{O}$ & 0.1000 & & & \\
\hline
\end{tabular}

${ }^{a}$ Noble metals: $\mathrm{PdO} 0.00072, \mathrm{Rh}_{2} \mathrm{O}_{3} 0.00024$, and $\mathrm{RuO}_{2} 0.00144$ 
Table 3a. Glass compositions in mass fractions of simple oxides [[33]]

\begin{tabular}{lccccccc} 
Glass ID & $\mathrm{NiO}$ & $\mathrm{Cr}_{2} \mathrm{O}_{3}$ & $\mathrm{Fe}_{2} \mathrm{O}_{3}$ & $\mathrm{Al}_{2} \mathrm{O}_{3}$ & $\mathrm{Li}_{2} \mathrm{O}$ & $\mathrm{RuO}_{2}$ & Others \\
\hline Baseline & 0.0064 & 0.0017 & 0.1451 & 0.0821 & 0.0199 & 0.0000 & 0.7448 \\
Ni1.29 & 0.0129 & 0.0017 & 0.1441 & 0.0816 & 0.0198 & 0.0000 & 0.7399 \\
$\mathrm{Cr} 0.3$ & 0.0064 & 0.0030 & 0.1448 & 0.0820 & 0.0199 & 0.0000 & 0.7439 \\
$\mathrm{Ni1.5/Al10}$ & 0.0150 & 0.0017 & 0.1408 & 0.1000 & 0.0193 & 0.0000 & 0.7232 \\
$\mathrm{Ni1.5/Fe17.5}$ & 0.0150 & 0.0016 & 0.1750 & 0.0784 & 0.0190 & 0.0000 & 0.7110 \\
$\mathrm{Ni1.5/Li3.8}$ & 0.0150 & 0.0017 & 0.1410 & 0.0799 & 0.0380 & 0.0000 & 0.7244 \\
Ni1.5/CrO.3 & 0.0150 & 0.0030 & 0.1436 & 0.0813 & 0.0197 & 0.0000 & 0.7374 \\
Ni1.5/Ru0.015 & 0.0150 & 0.0017 & 0.1437 & 0.0814 & 0.0197 & 0.00015 & 0.7384 \\
Ni1.5/Ru0.087 & 0.0150 & 0.0017 & 0.1436 & 0.0813 & 0.0197 & 0.00087 & 0.7378
\end{tabular}

Table $3 \mathrm{~b}$. Glass compositions in mass fractions of simple oxides and spinels

\begin{tabular}{lrrrrrrr} 
Glass ID & $\mathrm{NiFe}_{2} \mathrm{O}_{4}$ & $\mathrm{NiCr}_{2} \mathrm{O}_{4}$ & $\mathrm{Fe}_{3} \mathrm{O}_{4}$ & $\mathrm{Al}_{2} \mathrm{O}_{3}$ & $\mathrm{Li}_{2} \mathrm{O}$ & $\mathrm{RuO}_{2}$ & Others \\
\hline Ni1.29 & 0.0379 & 0.0025 & 0.1144 & 0.0816 & 0.0198 & 0.00000 & 0.7439 \\
Cr0.3 & 0.0155 & 0.0045 & 0.1298 & 0.0820 & 0.0199 & 0.00000 & 0.7484 \\
$\mathrm{Ni1.5/Al10}$ & 0.0444 & 0.0025 & 0.1068 & 0.1000 & 0.0193 & 0.00000 & 0.7269 \\
Ni1.5/Fe17.10 & 0.0446 & 0.0024 & 0.1398 & 0.0784 & 0.0190 & 0.00000 & 0.7158 \\
Ni1.5/Li3.10 & 0.0444 & 0.0025 & 0.1070 & 0.0799 & 0.0380 & 0.00000 & 0.7281 \\
Ni1.5/Cro.10 & 0.0424 & 0.0045 & 0.1109 & 0.0813 & 0.0197 & 0.00000 & 0.7412 \\
Ni1.5/Ru0.015 & 0.0444 & 0.0025 & 0.1096 & 0.0814 & 0.0197 & 0.00015 & 0.7421 \\
Ni1.5/Ru0.087 & 0.0444 & 0.0025 & 0.1095 & 0.0813 & 0.0197 & 0.00087 & 0.7416
\end{tabular}

Table 4. "Others" composition in mass fractions [[33]]

\begin{tabular}{ll|ll}
$\mathrm{B}_{2} \mathrm{O}_{3}$ & 0.1073 & $\mathrm{MgO}$ & 0.0018 \\
$\mathrm{BaO}$ & 0.0012 & $\mathrm{MnO}$ & 0.0047 \\
$\mathrm{CaO}$ & 0.0076 & $\mathrm{Na}_{2} \mathrm{O}$ & 0.2505 \\
$\mathrm{CdO}$ & 0.0087 & $\mathrm{Nd}_{2} \mathrm{O}_{3}$ & 0.0024 \\
$\mathrm{Ce}_{2} \mathrm{O}_{3}$ & 0.0027 & $\mathrm{P}_{2} \mathrm{O}_{5}$ & 0.0043 \\
$\mathrm{Cl}$ & 0.0003 & $\mathrm{SiO}_{2}$ & 0.5412 \\
$\mathrm{CoO}$ & 0.0001 & $\mathrm{SnO}_{2}$ & 0.0014 \\
$\mathrm{CuO}$ & 0.0005 & $\mathrm{SO}_{3}$ & 0.0011 \\
$\mathrm{~F}$ & 0.0001 & $\mathrm{TiO}_{2}$ & 0.0004 \\
$\mathrm{~K}_{2} \mathrm{O}$ & 0.0046 & $\mathrm{ZnO}$ & 0.0003 \\
$\mathrm{La}_{2} \mathrm{O}_{3}$ & 0.0030 & $\mathrm{ZrO}_{2}$ & 0.0558
\end{tabular}


Table 5. Equilibrium content of spinel phase in glasses in mass fractions [[33]]

\begin{tabular}{|c|c|c|c|c|c|c|c|c|c|c|c|}
\hline$T,{ }^{\circ} \mathrm{C}$ & 850 & 875 & 900 & 926 & 950 & 1000 & 1008 & 1025 & 1050 & 1070 & 1080 \\
\hline $\mathrm{Ni1.29}$ & 0.0268 & 0.0225 & 0.0206 & 0.0151 & 0.0099 & 0.0038 & & & & & \\
\hline $\mathrm{CrO} .3$ & 0.0094 & 0.0074 & 0.0045 & & & & & & & & \\
\hline Ni1.5/Al10 & 0.0406 & 0.0418 & 0.0379 & 0.0329 & 0.0297 & 0.0253 & 0.0193 & 0.0169 & 0.0071 & & \\
\hline Ni1.5/Fe17.5 & 0.0530 & 0.0533 & 0.0484 & 0.0421 & 0.0398 & 0.0347 & 0.0334 & 0.0293 & 0.0260 & 0.0229 & 0.0184 \\
\hline Ni1.5Li3.8 & 0.0328 & 0.0305 & 0.0245 & 0.0208 & 0.0171 & 0.0097 & & & & & \\
\hline $\mathrm{Ni1} .5 / \mathrm{Cr} 0.3$ & 0.0331 & 0.0289 & 0.0269 & 0.0211 & 0.0178 & 0.0132 & 0.0072 & 0.0026 & & & \\
\hline Ni1.5Ru0.015 & 0.0347 & 0.0291 & 0.0271 & 0.0206 & 0.0174 & & & & & & \\
\hline Ni1.5Ru0.087 & 0.0339 & 0.0317 & 0.0266 & 0.0224 & 0.0175 & 0.0135 & 0.0108 & 0.0062 & 0.0019 & & \\
\hline
\end{tabular}

Table 6. Impact of Rules 1 and 2 on Schweiger at al. [[22]] database

$\begin{array}{lr}\text { Number of glasses with spinel primary phase } & 35 \\ \text { Number of data } & 164 \\ \text { Number of data with } c_{0}>0 & 129 \\ \text { Number of spinel compositions containing only } \mathrm{Cr}_{2} \mathrm{O}_{3} \text { and } \mathrm{NiO} & 13 \\ \text { Number of spinel compositions with } f_{\mathrm{Cr} 203}=200 & 112 \\ \text { Number of spinel compositions with } f_{\mathrm{NiO}}=50 & 67\end{array}$

Table 7. Liquidus temperature coefficients $\left(T_{i}\right)$ in ${ }^{\circ} \mathrm{C}$

\begin{tabular}{|c|c|c|c|c|c|c|c|c|}
\hline & \multirow[t]{2}{*}{ Model 1} & \multirow[t]{2}{*}{ Model 2} & \multicolumn{2}{|c|}{ Schweiger et al. [[22]] } & \multirow{2}{*}{$\begin{array}{l}\text { Mika et al. } \\
{[[2]]}\end{array}$} & \multicolumn{2}{|c|}{ Hrma et al. } & \multirow{2}{*}{$\begin{array}{c}\text { Wilson et al. } \\
{[[10]]}\end{array}$} \\
\hline & & & Optical & XRD & & {$[[]$} & & \\
\hline $\mathrm{Cr}_{2} \mathrm{O}_{3}$ & 29781 & 39169 & 26835 & 30792 & 27108 & 19242 & 21038 & 20578 \\
\hline $\mathrm{NiO}$ & 15788 & 15592 & 9405 & 10837 & 9445 & 8629 & 9231 & 9573 \\
\hline $\mathrm{Fe}_{2} \mathrm{O}_{3}$ & 2992 & 3202 & 2677 & 3083 & 2700 & 2605 & 2730 & 2670 \\
\hline $\mathrm{MnO}$ & 1790 & 1442 & 2875 & 1336 & 507 & 1962 & 958 & \\
\hline$N M^{(a)}$ & 20582 & 21619 & & & & 31192 & 15461 & \\
\hline $\mathrm{Al}_{2} \mathrm{O}_{3}$ & 2637 & 2560 & 2975 & 3572 & 2777 & 3330 & 2980 & 2848 \\
\hline $\mathrm{B}_{2} \mathrm{O}_{3}$ & 667 & 616 & 646 & 573 & 346 & 363 & 304 & \\
\hline $\mathrm{SiO}_{2}$ & 999 & 754 & 981 & 866 & 1004 & 838 & 993 & \\
\hline $\mathrm{P}_{2} \mathrm{O}_{5}$ & 1623 & 1569 & 2859 & 1822 & & & & \\
\hline $\mathrm{Bi}_{2} \mathrm{O}_{3}$ & 554 & 150 & 719 & 966 & & & & \\
\hline $\mathrm{ZrO}_{2}$ & 983 & 864 & 1572 & 1356 & & & & \\
\hline $\mathrm{CaO}$ & 294 & 405 & -230 & 37 & 2215 & & 2162 & \\
\hline $\mathrm{MgO}$ & & & & & 4345 & 2900 & 3592 & 2657 \\
\hline $\mathrm{Li}_{2} \mathrm{O}$ & -2983 & -2431 & -3316 & -7027 & -1639 & -1599 & -1587 & -1333 \\
\hline $\mathrm{Na}_{2} \mathrm{O}$ & -1453 & -1461 & -1664 & -2029 & -1565 & -1851 & -1654 & -1756 \\
\hline $\mathrm{K}_{2} \mathrm{O}$ & -1037 & -839 & -1782 & -1138 & -885 & & -711 & \\
\hline $\mathrm{F}$ & 72 & -392 & 1134 & 1108 & & & & \\
\hline Others & 2474 & 7763 & 7670 & 15014 & & & & 1195 \\
\hline$R^{2}$ & 0.948 & 0.967 & 0.957 & 0.951 & 0.970 & 0.940 & 0.960 & 0.968 \\
\hline
\end{tabular}


Table 8. Liquidus temperature coefficients $\left(T_{i}\right)$ based on simple oxides (Table $3 a$ ) and on Ni-Cr-Fe spinels (Table 3b)

\begin{tabular}{lr|lr} 
& $T_{i}\left({ }^{\circ} \mathrm{C}\right)$ & & $\mathrm{T}_{i}\left({ }^{\circ} \mathrm{C}\right)$ \\
\hline $\mathrm{NiO}$ & 15709 & $\mathrm{NiFe}_{2} \mathrm{O}_{4}$ & 8150 \\
$\mathrm{Cr}_{2} \mathrm{O}_{3}$ & 3071 & $\mathrm{NiCr}_{2} \mathrm{O}_{4}$ & 6301 \\
$\mathrm{Fe}_{2} \mathrm{O}_{3}$ & 4723 & $\mathrm{Fe}_{3} \mathrm{O}_{4}$ & 4882 \\
$\mathrm{RuO}_{2}$ & 16445 & $\mathrm{RuO}_{2}$ & 16390 \\
$\mathrm{Al}_{2} \mathrm{O}_{3}$ & 4284 & $\mathrm{Al}_{2} \mathrm{O}_{3}$ & 4274 \\
$\mathrm{Li}_{2} \mathrm{O}$ & 841 & $\mathrm{Li}_{2} \mathrm{O}$ & 825 \\
Others & -333 & Others & -320 \\
\hline$R^{2}$ & 0.983 & $R^{2}$ & 0.983
\end{tabular}

Table 9. Spinel composition (in mass fractions) based on Schweiger et al. [[22]] data (Model 1) and Matyas et al. [[33]] data (fitted to compositions based on simple oxides [left column] and $\mathrm{Ni}-\mathrm{Cr}-\mathrm{Fe}$ spinels [right column])

\begin{tabular}{l|ccc|cc} 
& \multicolumn{3}{|c|}{ Schweiger et al. } & \multicolumn{2}{c}{ Matyas et al. } \\
& Max. & Min. & Average & Oxides & Spinels \\
\hline $\mathrm{Cr}_{2} \mathrm{O}_{3}$ & 0.6705 & 0.0605 & 0.1783 & 0.0300 & 0.0295 \\
$\mathrm{Fe}_{2} \mathrm{O}_{3}$ & 0.6582 & 0.0000 & 0.4996 & 0.8011 & 0.8101 \\
$\mathrm{NiO}$ & 0.3295 & 0.0909 & 0.3221 & 0.1689 & 0.1604 \\
\hline $\mathrm{NiCr}_{2} \mathrm{O}_{4}$ & 1.0000 & 0.0000 & 0.7373 & 0.0479 & 0.0447 \\
$\mathrm{NiFe}_{2} \mathrm{O}_{4}$ & 0.9098 & 0.0000 & 0.2484 & 0.4843 & 0.4657 \\
$\mathrm{FeCr}_{2} \mathrm{O}_{4}$ & 0.7147 & 0.0000 & 0.0108 & & \\
$\mathrm{Fe}_{3} \mathrm{O}_{4}$ & 0.2905 & 0.0000 & 0.0035 & 0.4678 & 0.4896
\end{tabular}


Table 10. Estimated and measured $T_{L}$ of test glasses and the theoretical maximum spinel content

\begin{tabular}{lrrrll} 
& \multicolumn{1}{c}{$T_{L}^{\text {o(a) }}$} & \multicolumn{1}{c}{$T_{L}^{\text {o(b) }}$} & \multicolumn{1}{c}{$T_{L}^{\text {o(c) }}$} & \multicolumn{1}{l}{$C_{M}$} & \multicolumn{1}{c}{$C_{\max }$} \\
\hline Ni1.29 & 1008 & 949 & 950 & 0.188 & 0.155 \\
Cro.3 & 914 & 988 & 1005 & 0.175 & 0.150 \\
Ni1.5/Al10 & 1109 & 1074 & 1075 & 0.203 & 0.154 \\
Ni1.5/Fe17.5 & 1182 & 1125 & 1105 & 0.214 & 0.187 \\
Ni1.5/Li3.8 & 1040 & 1012 & 1004 & 0.193 & 0.154 \\
Ni1.5/Cro.3 & 1042 & 1021 & 1018 & 0.193 & 0.158 \\
Ni1.5/Ru0.015 & 1041 & 1051 & 1087 & 0.193 & 0.157 \\
Ni1.5/Ru0.087 & 1052 & 1061 & 1085 & 0.195 & 0.156 \\
\hline
\end{tabular}

(a) Based on Table 8 coefficients

(b) Mesured via XRD [[33]]

(c) Measured optically [[33]]

Table 11. Composition regions of test glasses and matrix glasses in mass fractions of components for Matyas et al. [[33]] data (model fitted to compositions expressed in simple oxides)

\begin{tabular}{lcccccc} 
& \multicolumn{2}{c}{ Minimum } & \multicolumn{2}{c}{ Maximum } & Range $^{(a)}$ & $\begin{array}{c}\text { Increase } \\
\text { Ratio }\end{array}$ \\
\hline $\mathrm{NiO}$ & 0.0064 & 0.0049 & 0.0150 & 0.0147 & 0.0101 & 1.18 \\
$\mathrm{Cr}_{2} \mathrm{O}_{3}$ & 0.0016 & 0.0000 & 0.0030 & 0.0029 & 0.0030 & 2.14 \\
$\mathrm{Fe}_{2} \mathrm{O}_{3}$ & 0.1408 & 0.1120 & 0.1750 & 0.1712 & 0.0630 & 1.84 \\
$\mathrm{Al}_{2} \mathrm{O}_{3}$ & 0.0784 & 0.0789 & 0.1000 & 0.1044 & 0.0009 & 1.20 \\
$\mathrm{Li}_{2} \mathrm{O}$ & 0.0190 & 0.0191 & 0.0380 & 0.0393 & 0.0260 & 1.07 \\
Others & 0.7110 & 0.7153 & 0.7448 & 0.7649 & 0.0203 & 1.59 \\
\hline
\end{tabular}

(a) Range covers test glasses plus matrix glasses.

(b) The $i$-th component Increase Ratio equals the (overall) $i$-th component range divided by the $i$-th component range in test glasses. 


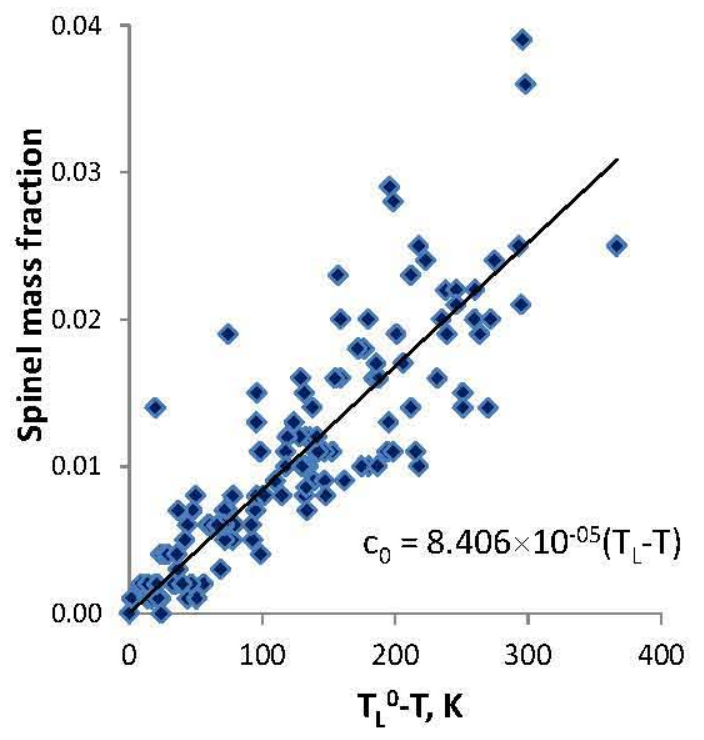

Fig. 1 Spinel mass fraction versus undercooling below optically determined $T_{L}$. 


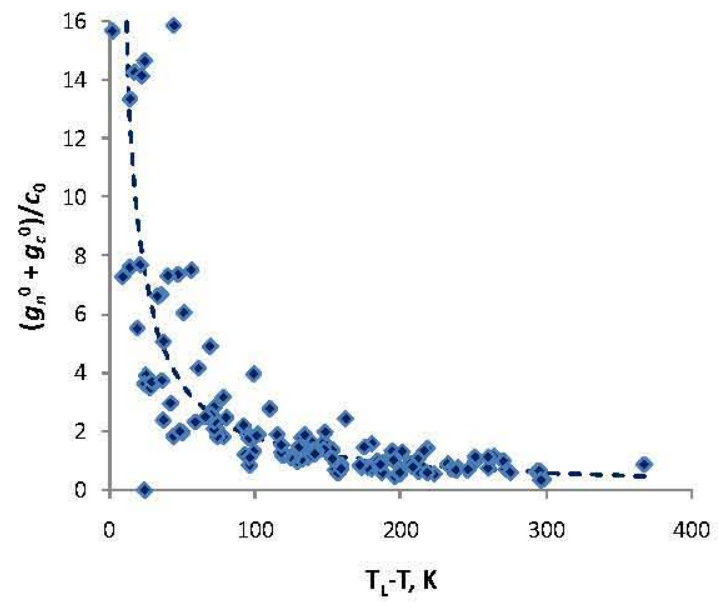

Fig. 2. Ratio of $\mathrm{NiO}+\mathrm{Cr}_{2} \mathrm{O}_{3}$ mass fractions in glass to $c_{0}$ versus undercooling below optically determined $T_{L}$; the trend line is a hyperbola $y=x_{0} / x$, where $y=\left(g_{n}{ }^{0}+g_{c}{ }^{0}\right) / c_{0}, x=T_{L}{ }^{0}-T$, and $x_{0}=180 \mathrm{~K}$. 


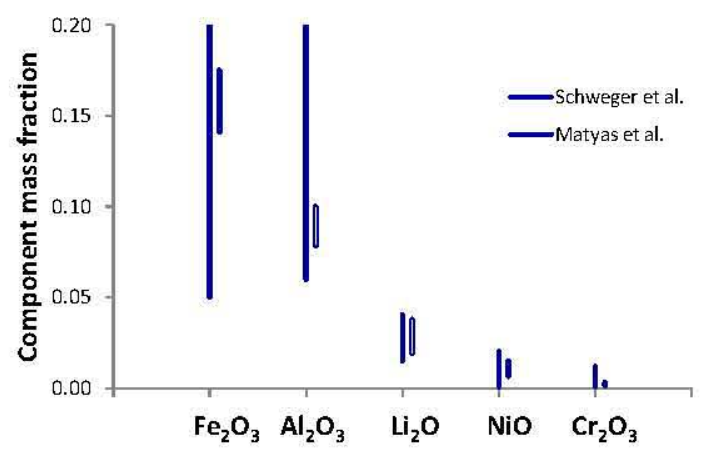

Fig. 3. Matrix glass component ranges for glasses varying the components shown based on data sets by Schweiger et al. [[22]] and Matyas et al. [[33]] 


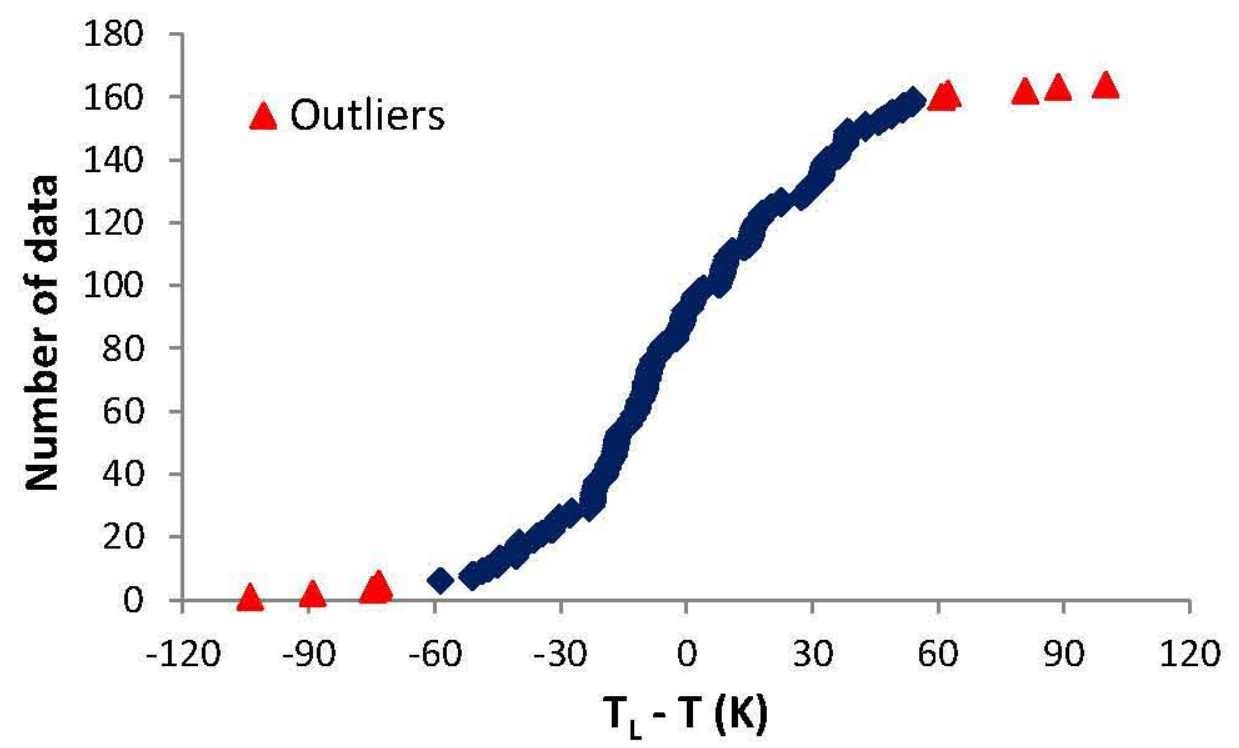

Fig. 4. Cumulative histogram of deviations between estimated $T_{L}$ and heat-treatment temperature (Model 1) 

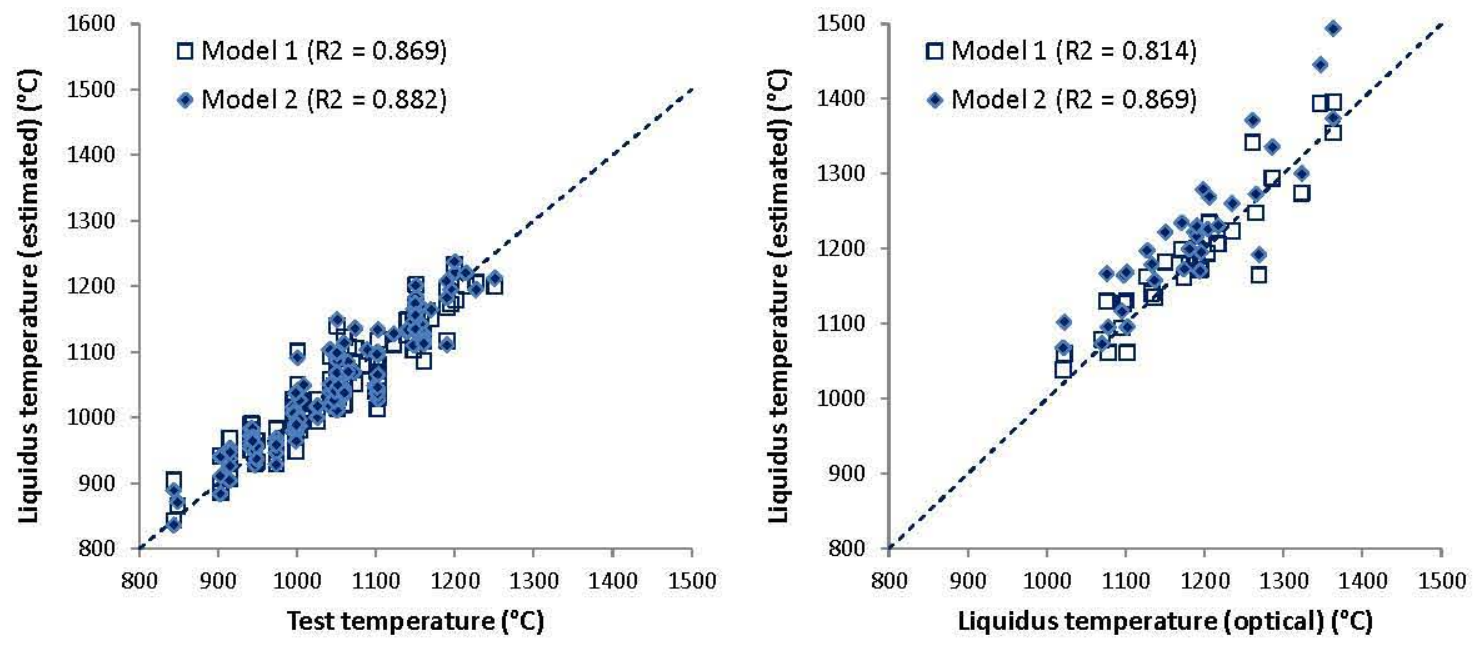

Fig. 5. Estimated $T_{L}$ versus test temperature (left) and optically measured $T_{L}$ (right); R2 in the legend denoted the correlation coefficient $\left(R^{2}\right)$ 


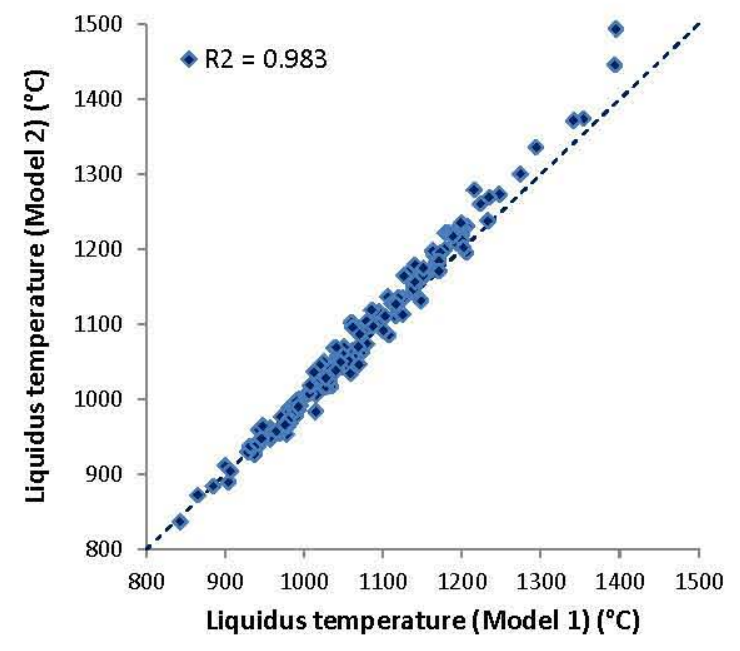

Fig. 6. Estimated $T_{L}$, Model 2 versus Model 1 

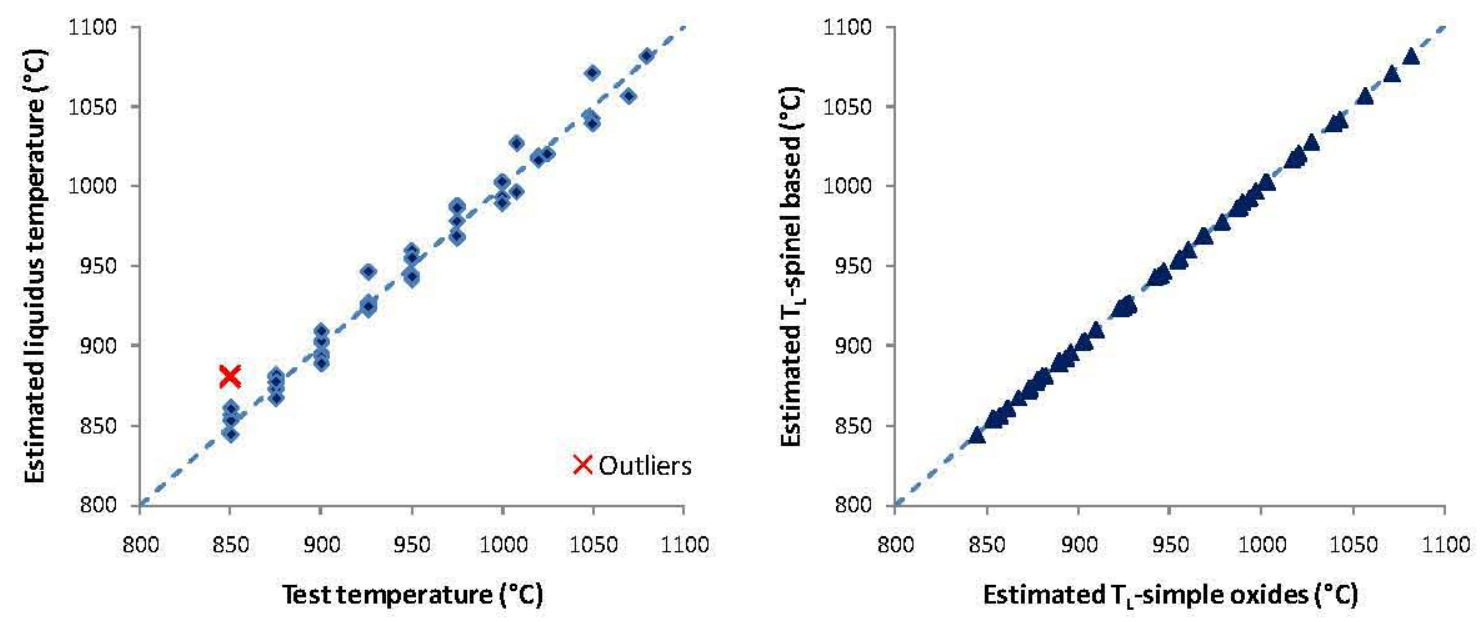

Figure 7. Estimated $T_{L}$ versus test temperature (left); comparison of $T_{L}$ estimates based on alternative ways of expressing glass composition (right) 

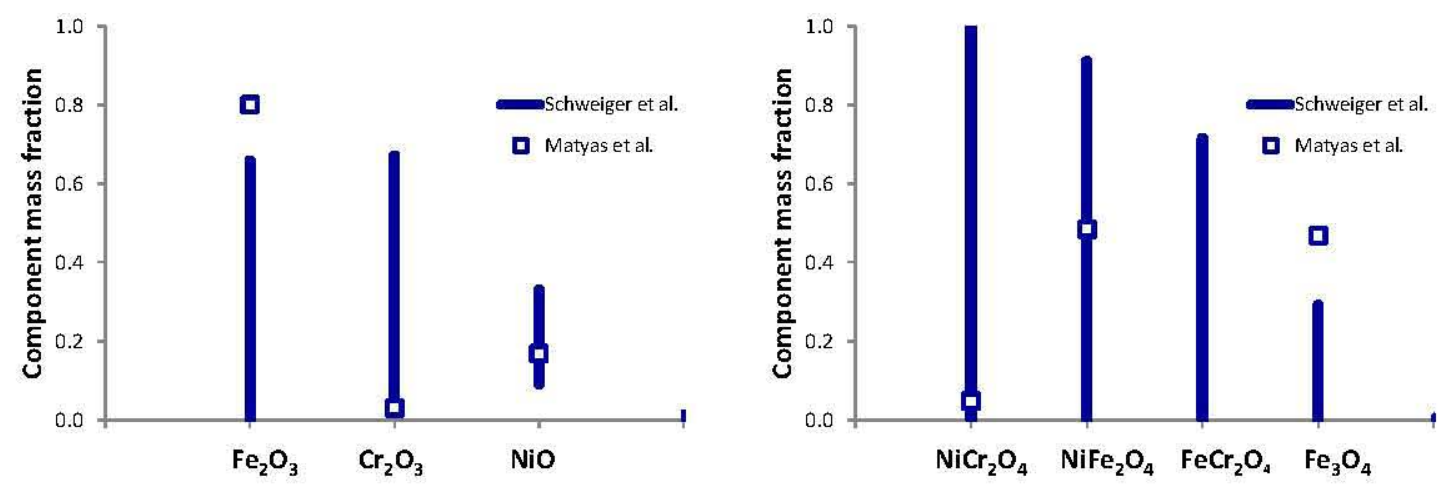

Fig. 8. Spinel composition based on Schweiger et al. [[22]] data (Model 1) and Matyas et al. [[33]] data 


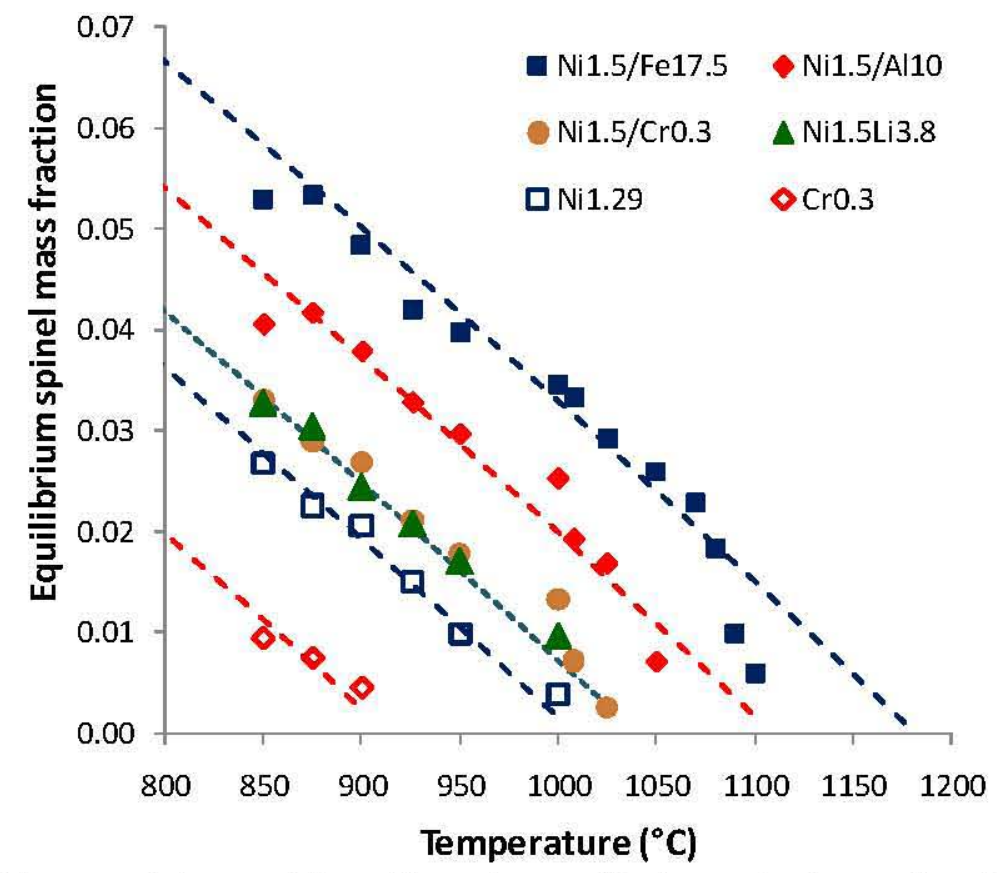

Fig. 9. Measured data and fitted lines for equilibrium spinel mass fraction [33] 